\title{
RELIABILITY AND SUSTAINABILITY ANALYSIS \\ OF LARGE PANEL RESIDENTIAL BUILDINGS IN SOFIA, SKOPJE AND NOVI SAD
}

$U D C 728.2(497.223)(497.17)(497.113)=111$

\author{
Radomir Folić*, Mirjana Laban, Verica Milanko \\ University of Novi Sad, Faculty of Technical Science, Serbia \\ folic@uns.ac.rs
}

\begin{abstract}
Large panel residential buildings, dating from second half of 20 Century, are to be found in almost every urban settlement across Europe. Within the context of three case studies of urban blocks in Bulgaria (Mladost - Sofia), Macedonia (Karpos III - Skopje) and Serbia (Detelinara - Novi Sad), comparative analysis and evaluation of technical and structural characteristics according to reliability (seismic resistance and fire safety) and sustainability (energy efficiency, internal air quality, accessibility) criteria has been conducted. Additionally, previous experiences from individual renewal projects are reviewed. Previous experiences and comparative analysis results, could contribute to formulation of wider applicable solutions and development of new urban renewal strategies.
\end{abstract}

Key words: large panel residential buildings, comparative analysis, reliability, sustainability, renewal.

\section{INTRODUCTION}

In The Sofia Declaration on the Future of Large Prefabricated Housing Estates in Central and Eastern Europe (1997) it was proclaimed that in Central and Eastern Europe, more than 34 million people live in app. 600 housing estates of over 2.500 units, which were built during the state socialist period. Including the states of the former USSR, the large prefabricated estates are the homes of 170 million people, which were built between the 1960s and 1990 [1]. The physical and moral decay [2] of the buildings and the infrastructure, due to lack of maintenance and inadequate management structures after privatization, are listed as problem which could lead to serious endangerment of this huge housing stock. Proposed coordinated activities, for social, economic and environmental 
revitalization of those buildings, included intensive cooperation and knowledge transfer, involvement of financial international support.

Beside political and social conditions, common influence on housing development, in our region, has also major destruction caused by the Second World War, rapidly growing urban population levels due to migration from rural areas, industrialization, as well as desire to do better than traditional housing. While the flats themselves were often small, the standard of social and cultural infrastructure (schools, program for youth, cultural centres and clubs, parks, recreation areas) was usually very good and most areas were built with god connections via public transport to workplaces and city centres. Despite some similarities found in housing projects in the former state socialist countries between 1960 and 1990, the qualities of the buildings and construction standards vary greatly. Growing pressures of rationalization and economically forced cost-cutting, especially in the last decade, reduced the quality of construction and building maintenance. Significant number of those structures therefore occurred as decaying dwellings [3,4], in neglected urban areas [5], suffering problems caused by the use of polluting building materials (e.g. asbestos), lack of insulation [6], and a complete absence of energy efficient technologies, wasteful water management system [7], and poor fire-safety preventive measures [8]. Illegal building interventions, mostly performed by tenants themselves, often are done applying inadequate designing, poor building materials and bad construction methods [9], additionally impacts on residential quality of dwellings and urban settlement in hole.

Large panel building systems were applied in almost every European country and in Bulgaria, Macedonia and Serbia as well. These countries and towns also have other similarities: social development issues, privatization of apartments and new owners' financial problems, and, may be the most important issue - people's mentality. So far, numerous research programs on this topic were realized with support of different European institutions and founds. Research teams from our countries took a part in some of them, but never all three country representatives in the same one, so the research results are rarely comparable, because of different evaluation criteria applied.

This paper presents comparatively analyzed and evaluated research results regarding large panel building blocks in Sofia (Bulgaria), Skopje (Macedonia) and Novi Sad (Serbia). Comparative valorisation criteria are ranged according to importance to buildings usability, life safety and common consequence to our cities.

\section{PANEl Urban BuILdings Block COMPARATIVE ANALysis CRITERIA}

The structural and technical characteristics of applied building systems in Sofia, Skopje and Novi Sad are summarized in each case study. Flexibility of building plan depends on type of load-bearing structure of building. In the most of the cases, load-bearing walls structure doesn't allow too many possibilities for internal space redesigning. Urban renovation and building refurbishment include a wide range of aspects to be considered, such as it was formulated in COST Action C-16 [10]: design aspects (architectural, land use and planning aspects), technical aspects (building physics, structural and environmental aspects) and non technical aspects (managerial, financial, social and cultural aspects). According to the methodology conducted in named research program, numerous criteria resulted based on listed aspects. Key aspects (building physics, structural and en- 
vironmental) gave core criteria, and seismic resistance and fire safety are safety criteria applied in this research work too. Energy performance, humidity and presence of dangerous materials are applied as sustainability criteria. The large-panel residential buildings are designed and erected in compliance with the current regulations at the time of construction (1960-1990). Some of the criteria have been subsequently enhanced. Even the upgrading of buildings according to improved regulations were obligatory actions by low, in the most of the cases, it failed.

The seismic resistance aspect has to be seriously reconsidered in all renewal activities. Due to lack of proper maintains, those 30-40 years old structures are in pour condition. Additionally, there are evidenced numerous unskilled and irregular buildings activities, done by owners, in order to provide additional living space. The most of buildings were built in period with very few or any fire safety regulations. In renovating activities, it is necessary to assess fire risks and improve fire protective measures. Both seismic resistance and fire safety are the most important issues to provide buildings usability and residents' life safety. Safety evaluation [11] is performed in order to verify the safety (reliability) of an existing structure for future use.

Energy performance of buildings and energy saving became lately the priorities of sustainable urban development $[12,13]$. Improving thermal insulation and vapour barriers, also contributes to internal air quality and living conditions. Presence of the mould and dangerous materials, like asbestos, could endanger human health, so it is important to identify and eliminate them during renovation process $[14,15]$.

\section{BULGARIA - SOCIAL DiALOG AND ENERGY REFURBISHMENT OF BUILDINGS}

There is 11,128 large panel residential buildings in Bulgaria. 787,096 apartments [16]. These buildings consist 11,128 dwellings where live more than 2 milion people. The most of them (53\%) were built in 1980s and 1990 s, and $33 \%$ dating from 1970 s, which means that the age of those buildings is $20-40$ years, and that is valuable built inheritance for consideration in urban renewal actions. Large prefabricated panel is the dominant construction method (62\%) of high-rise dwellings (more than 4 stores) [17]. Over $98 \%$ of dwellings are privatized in $1990 \mathrm{~s}$, and $80 \%$ are owner occupied. Thought the process of economic liberation was followed by a breakdown of industries and a considerable loss of employment, new owners couldn't afford to invest in building maintains so most of the buildings suffer from decay of technical infrastructure, deteriorated envelopes and neglected public space in and around the buildings.

The analysis of the technical condition of the large-panel residential buildings [18] was made on the basis of the actual Bulgarian requirements towards buildings:

1. Bearing capacity, fire safety, noise protection - the large-panel residential buildings were designed and erected in compliance with the current regulations at the time of erection. Some of the criteria have been subsequently enhanced. Since 1987, there is a new zoning scheme of earthquake regions in Bulgaria, and Sofia is located within a zone of expected moderate and strong earthquakes. Fire rules for Bulgaria are given in 1987 for dwellings and dwelling buildings.

2. Energy efficiency - according to national statistical data for 2004 , about $40 \%$ of housing erected in the period $1919-2000$ has been built by $1950 ; 50 \%$ is built in the period 1961- 1991, and the remaining 10\% - in the period 1991-2000. The first thermo in- 
sulation standard dates from 1960, while the actual regulations were introduced in 1992 , updated in 1999 and 2004. According to analyses made in 1981 for the thermal engineering parameters of the existing housing by 1980, some large-panel residential buildings do not meet the current thermal engineering regulations for the cladding components and structures. Today, the insufficient thermal resistance of those buildings, taking into account the requirements of 2004 , varies from 0.50 to $1.60 \mathrm{~m} 2 \mathrm{~K} / \mathrm{W}$, depending on the type of the cladding components.

3. Easy access - with respect to the access of disabled people, the concrete panel buildings are unsuitable, due to the fact that they had been built several decades before the regulations for easy access came into force.

Generally, so far surveys and research programs (e.g. RESHAPE 2006-2008, SHARE 2006-2008, ROSH 2006-2008) [19-21], were primarily oriented to energy efficiency, but it was also found, that the load bearing structures are in good condition, although facades are deteriorated: numerous defects are evidenced, thermal insulation is insufficient and wooden window frames are devastated. It is necessary to repair flat roof terraces, both hydro and thermo insulation, and water drains as well. Buildings infrastructure is also aged and needs replacement. EI-Education program [22] conducted in 2006 was aimed to improve social dialog and enable municipalities and housing stock owners to perform energy intelligent retrofitting (saving at least 30\% energy compared to situation before the renovation), as well as ISEES project (2006-2007) [23]. The INOFIN project (20062008) [24] explored how cross-national initiatives can be linked with international financing institutions.

The priority of National Program for Renovation of Multifamily buildings in Republic of Bulgaria [25] are the panel residential buildings. The Program foresees within the 2006 - 2020 period 684,683 dwellings to be renovated. The first phase (till 2015) includes 105,000 dwellings from the panel complexes of Burgas, Varna, Plovdiv and Sofia, and the second phase has in scope 579,676 dwellings countrywide. The State will support the panel dwelling owners by means of direct subsidy of $20 \%$ from the renovation total value.

\subsection{Large panel building block in Mladost 3 district, Sofia}

The city of Sofia growth from 350,000 inhabitants in 1961, to over 1,1 million in 1995 [26]. Large panel production for residential buildings was organized in three factories in city area, which provided the rapid expansion of housing for growing population.

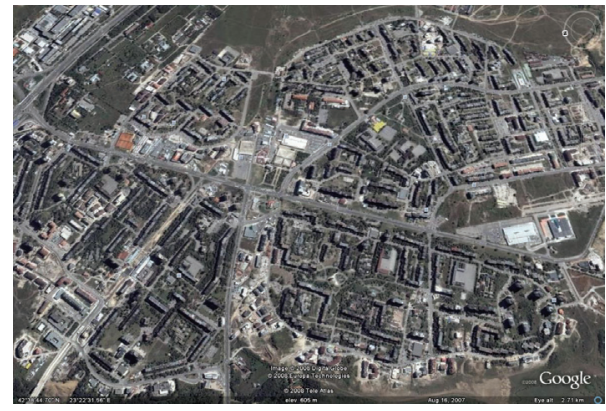

Fig. 1. Mladost city area, Sofia

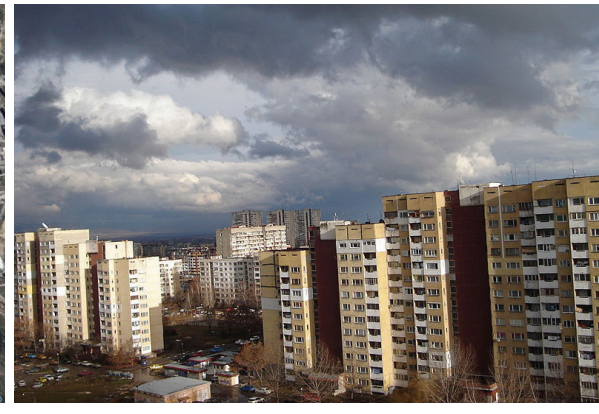

Fig. 2. Typical building block elevation 
Nowadays, there are 27 large, prefabricated housing estates, situated in second urban circle, with $60 \%$ of city inhabitants. There are 517,436 dwellings in the capital city, 324,403 of them being reinforced concrete ones, incl. 185,000 of the concrete panel type, occupied by aprox. 700,000 people [17].

Mladost district (Fig.1) is residential urban area, built between 1968 and 1989, in a continuous process and in accordance with its proposed plan. It clearly follows the idea of the 'socialist housing complex', with a 5 groups of blocks of flats and corresponding social infrastructure (school, kindergarten, retirement homes, district hospital) which has resulted in the development of distinct neighbourhoods. There are over 105,000 inhabitants in 204 building blocks (38,868 apartments). Average number of dwellings per building is 21-27 per section, and average floor space per flat is $75-80 \mathrm{~m}^{2}$ [26].

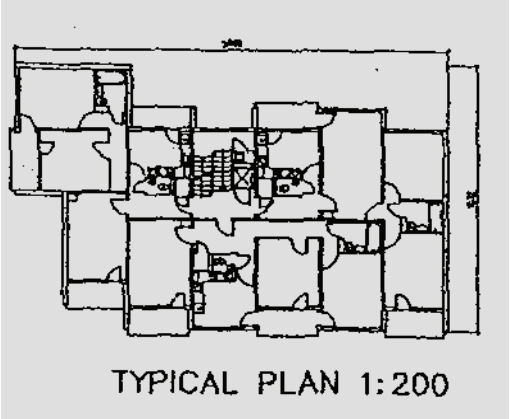

Fig. 3. Typical building plan

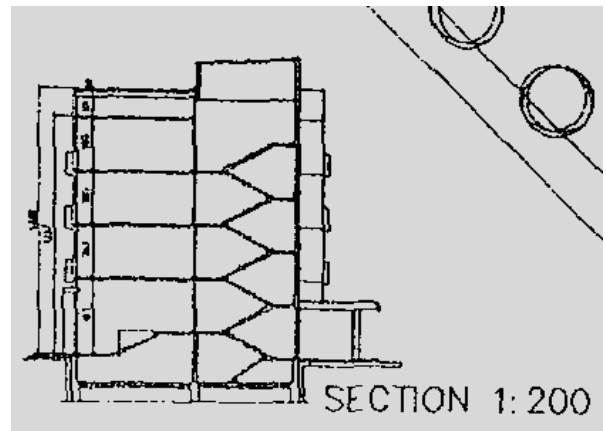

Fig. 4. Building section, after [27]

Predominant building type is concrete panel buildings, with 5 and 8-10 stories. The complex is typical of Bulgarian mass residential building (Fig.2) dating from 1980s. It is constructed with prefabricated walls, floors and roofs. Longitudinal span of supporting walls, made of $14 \mathrm{~cm}$ thick prefabricated concrete panels, is $3.6 \mathrm{~m}$ (Fig 3). Non-bearing internal walls are constructed of prefabricated $6 \mathrm{~cm}$ thick concrete panels, while external walls are constructed of prefabricated light concrete panels, with $20 \mathrm{~cm}$ thickness on the elevations and $26 \mathrm{~cm}$ thickness on the blank wall. The slabs are $14 \mathrm{~cm}$ thick prefabricated concrete elements. The roof contains of two $100 \mathrm{~mm}$ thick concrete panels with $101 \mathrm{~cm}$ inaccessible space between (Fig.4), and bad executed thermal insulation [27]. The outer reinforced concrete $(\mathrm{RC})$ panel has a waterproof covering. Double glazed windows with a gap of $24 \mathrm{~mm}$ are constructed of timber frames cast into the reinforced concrete wall panels.

The complexes Mladost 1, 1a, 2, 3, and 4 (Fig 1) are divided by relatively wide roads and areas that were originally aimed for future development. They include carefully planned as well as natural green areas, but there are not enough parking spaces for the increasing number of private cars. The lack of commercial space has spurred the growth of haphazard, small markets, while some of the shopping facilities are standing empty because of the financial problems faced by small shopkeepers.

The Demonstration Project for the Renovation of Multifamily Buildings is a joint initiative of the Ministry of Regional Development and Public Works and the United Nations Development Programme, which started in 2007. Till June 2010, 27 multifamily 
buildings and their surrounding public areas fully renovated, and another 23 buildings undergoing renovation (technical and energy surveys executed and design documentation prepared) [28].
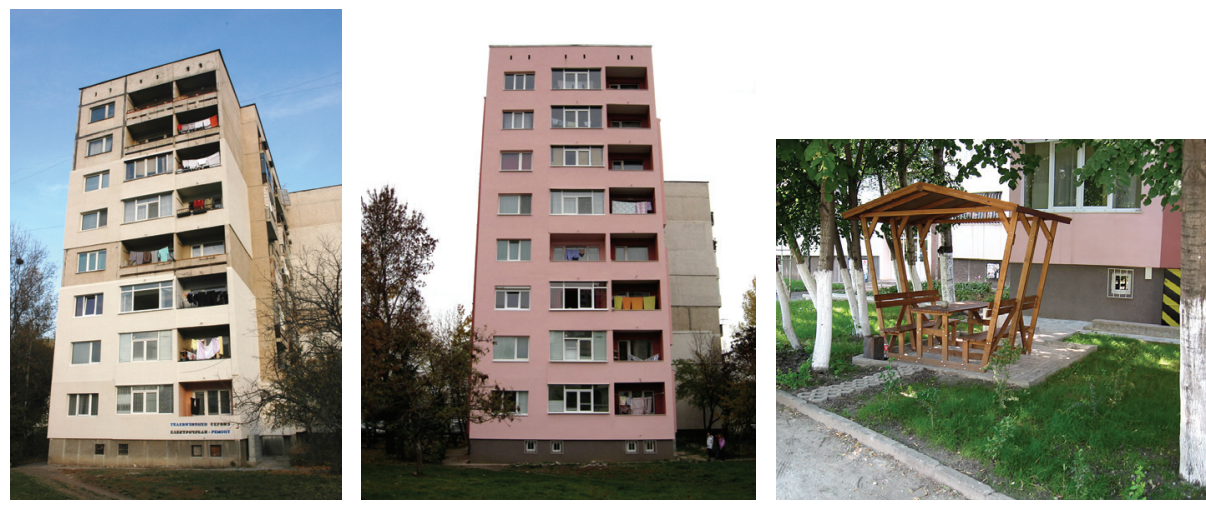

Fig. 5-7. Façade before and after refurbishment and surrounding, after [28]

One of completed renovation works was done on large panel building block 355, in Mladost 3 district, Sofia city area. The Project foresees the implementation of energy efficiency measures (thermal and hydro insulation, replacement of windows and doors, treatment of the external façade panel joints, others recommended in the energy survey report), refurbishment on common parts related to energy efficiency and safe habitation (repair of the main entrance door, the roof overhang over the entrance and the entrance steps, painting of the stairwell walls, others recommended in the technical survey report), replacement of old internal plumbing systems (replacement of the vertical main water supply and waste drain pipes), and renovation of surrounding public areas (Fig. 5-7).

\section{MACEDONIA - LOOKING FOR NEW EsPrit: Problems, NeEdS, SOLUTIONS}

In Macedonia almost $75-80 \%$ of two million population lives in urban areas, and $50 \%$ of them in wider Skopje area [29]. The earthquake is marked as major risk and transitions, grey economy and regulations as major problems involved in building rehabilitation process. Seismic resistance of residential buildings before 1963 earthquake was at low level, so lot of those suffered damages and some collapsed. New rigorous seismic regulations and building standards were introduced in Macedonia after that, so it can be sad that the residential multi-story building fund dating after 1963 was much better quality and safe to relatively strong possible seismic activities in region. Around $70 \%$ of the present dwelling stock was built after 70s and it is still in a good condition.

Totally prefabricated, RC heavy panel system "Karpos" was introduced in Macedonian building industry in 1963, as donation of USSR government. A new factory was built in Skopje and in a next 20 years it produced 15,000 flats in Skopje and some other towns. Settlements are low dense populated (120-150 residents per hectare), consisting of four storey buildings, not higher then $12 \mathrm{~m}$ and pretty well sized open areas, arranged in simple 
orthogonal scheme (Fig. 8). An average size of apartment is $57 \mathrm{~m}^{2}$ [30]. The new built apartments were safe, chip and acceptable for most of residents, but inflexibility of structural system with modest architectural performance couldn't enable internal modifications in order to adjust living space to family needs.

Improper maintenance and illegal and unskilled building interventions (openings in bearing walls, enlargement of balconies (Fig. 9) and enlargement of existing buildings in both horizontal and vertical directions) are endangering the structural stability and safety, specially in seismic region such as Macedonia. There is very few examples with proper repair and strengthening, so it is necessary to strictly follow the code in future activities and to introduce proper monitoring and maintenance. Repair and strengthening of bearing walls with openings and construction if enlarged balconies are key issues to provide structure's reliability. Fire safety regulations have been changed and improved since the buildings were built, but there is only $30 \%$ of examples with proper maintenance, repair and improvement activities [31,32].

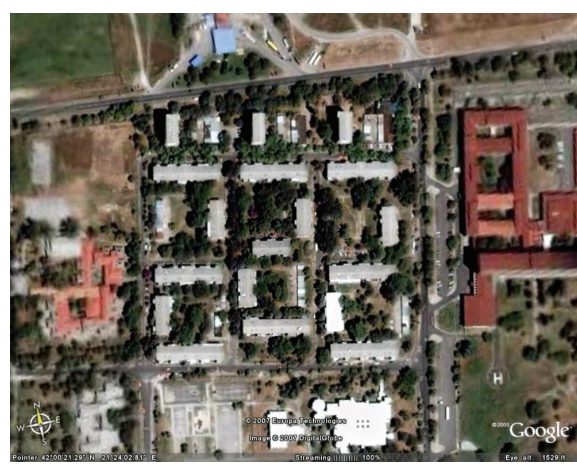

Fig. 8. Karpos settlement

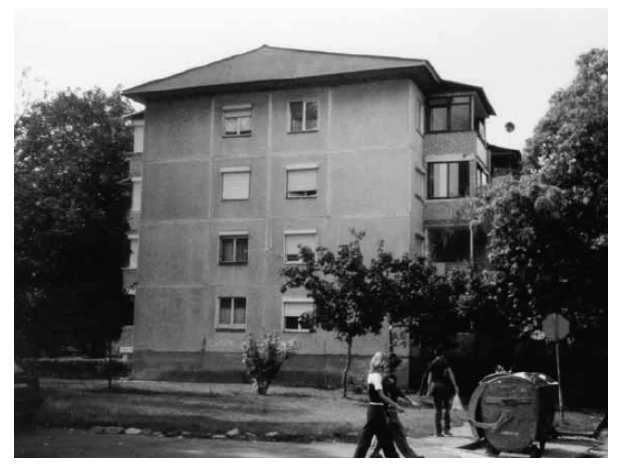

Fig. 9. Building elevation with "extensions"

As well as in Bulgaria, or Serbia, thermal insulation in residential buildings, was not subject of any serous consideration in Macedonia until mid 80s. Pour thermal insulation, high coefficient of external walls thermal conductivity and existence of many thermal bridges due to extensive use of concrete too, produces significant thermal problems. Same as Serbia, Macedonia inherited from the former SFRY standards: Requirements for design and manufacturing of buildings - MKS U.J5.600, Coefficient of heat transfer in buildings - MKS U.J5.510, Calculation of water vapor diffusion in buildings - MKS U.J5.520 and Characteristics of thermal stability of buildings - MKS U.J5.530., corrected by innovating the standards MKS U.J5.600 and MKS U.J5.510 in 1987. Furthermore, the relevant ISO and EN standards are adopted as national standards (ISO 6946, 7345, 9246, 9251, 9229, $1011-1 / 2,13789,14683)$. However these standards relate mainly to methodologies for calculating energy efficiency. They have not yet been applied to the specific (climatic, use categories and building age in Macedonia) conditions in Macedonia, nor have energy consumption norms been developed based on these calculations. A recent review of building related standards and codes in Macedonia indicates that there is no explicit legal requirement for developers to meet energy performance standards [33]. 
Hazardous substances can be found in asbestos cement roof and tiles and some chemicals used in construction (paints and varnish with synthetic solvents), so it is recommended to replace them with other roof covering materials. Also, the use of concrete as basic building material for residential buildings to such extend as in Karpos building system, in long term period of use can cause serious health problems and discomfort.

\subsection{Macedonia: Settlement Karpos, Skopje}

The settlement "Karpos" (Fig. 8) was built between 1964-66 on a block of land of $223.000 \mathrm{~m} 2$ and consist of five main spatial areas: there are two main residential blocks built in "Karpos" fully prefabricated system, orientated north-east and north west between the main street (boulevard) on the north and secondary street on the south, primary school plot, besides residential blocks built in classic RC skeleton system, kindergarten and high school. The two residential plots consist of total of 1344 flats built in a fully prefabricated heavy panels system. Each four storey residential building consists of combination of one bedroom flat $(31,50 \mathrm{~m} 2)$ to three bedroom flat $(84 \mathrm{~m} 2)$ (average size of flat $60 \mathrm{~m} 2 / \mathrm{flat}$ ) arranged on each level or of an. The residential blocks are arranged in orthogonal composition within narrow service streets and footpaths with enough open areas, landscaping and other urban facilities, and $18 \%$ of the plot was planed as parking areas distributed equally to the blocks [32].
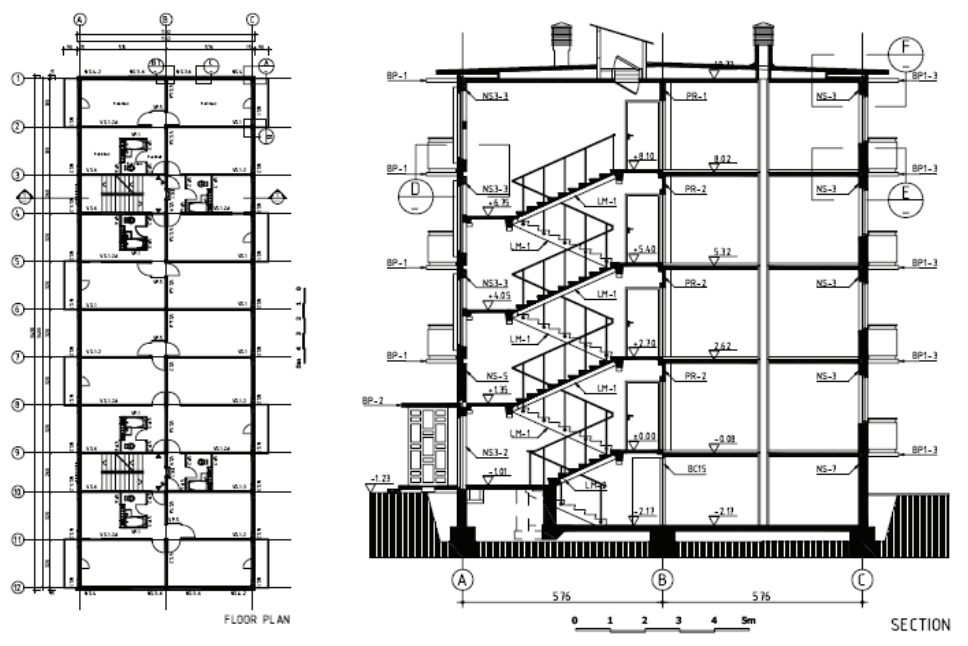

Fig. 10. Building floor plan and section (after [32])

Structurally, the perimeter wall panels, thick $25 \mathrm{~cm}$, consists of three basic stratums; External pre-cast RC panel thick $5 \mathrm{~cm}$, internal (structural) pre-cast RC panel thick $14 \mathrm{~cm}$ and Styrofoam or fibreglass thermal insulation thick $6 \mathrm{~cm}$ inserted in-between the panels. External and internal panels are structurally connected with concrete ribs. Horizontal and vertical perimeter wall panel joints are usually visible and sealed with special sponge hose from inside and elastic sealant from outside. Internal structural panels depending on their 
position are thick 12 and $14 \mathrm{~cm}$. The clean structural height of all wall panels is $270 \mathrm{~cm}$. For slab construction two basic modules of panels were used: $260 \times 576 \mathrm{~cm}$ and $320 \times 576$ $\mathrm{cm}$, both thick $10 \mathrm{~cm}$. The slab panels were connected to external or internal structural wall panels with special joints of steel framework and metal accessories, sealed later with cast concrete [32].

The flexibility of the flats (Fig. 10) is reduced to possibility to move internal not structural walls $(12 \mathrm{~cm}$ thick) and to improve or redesign the architectural plan lay out of the flats. Architectural barriers for handicapped persons within the buildings entries and stair case areas are also problems to be solved by introducing proper sized ramps or elevator units.
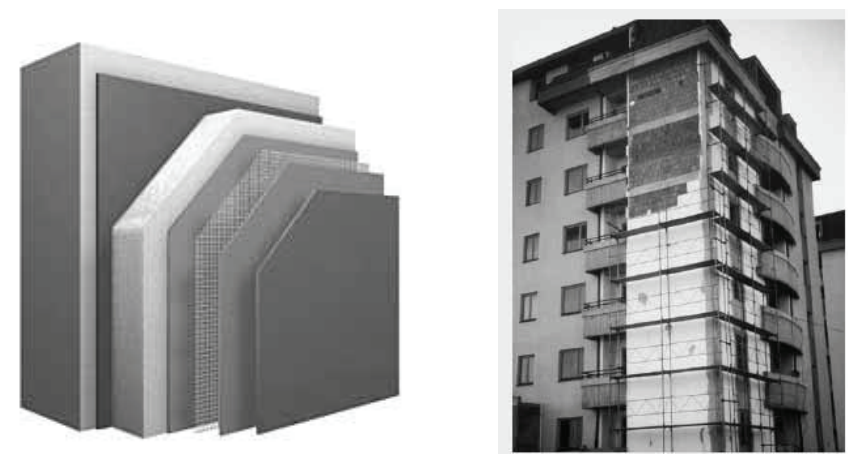

Fig. 11. "Externally Insulated Facade System" EIFS, after [33]

Proposed solution (Fig. 11), as the most adequate solution for improving thermal insulation, is to reconstruct the building envelopes with the "Externally Insulated Facade System" EIFS [33], which guaranties fulfilment of the demands from the present and forthcoming standards. The guaranties are based on the attests for the materials used for the implementation of the system and 20 years of experience gained in the process of implementation in Macedonia on new constructed buildings. Those contact façade solution, due to it's characteristics and performances, is in compliance with other contemporary reliability and sustainability criteria.

So far, there is no ongoing renovation activities supported by Macedonia government, financial institutions or EU institutions. General bad economic situation, luck of residents' financial capacities for proper building maintenance and refurbishment, could lead to serious damage to the buildings due to reconstruction delay. Long period of negligence caused to many problematic parts of building to be subjected to intervention and reconstruction and the problems could increase, unless the government and financial institutions create some beneficial or acceptable financial opportunities for owners to support renewal activities. 


\section{SERBIA - WAITING FOR BETTER TIMES FOR BUILDINGS' RENEAWAL}

The intensive applying of industrial technology of building period in Novi Sad, as well as in Serbia, was the same period as in Bulgaria and Macedonia; 1960 - 1990. In analyzed period of 30 years 41,220 apartments was built in Novi Sad: during the first and second decade more than 14,000 were completed, and around 12,000 in the third decade. In the next ten-year period (1990 - 1999) only 4,617 apartments were built [34]. Both large panel and skeleton system prefabricated building construction method were applied.

Most of built structures look similar, although the floor layout and flats were often planed at satisfactory level (kitchen with separated storage and dining, connected to living room with balcony, very often two bathrooms in flats containing more than one bedroom, or separated toilet from bathroom, quite night-part of apartment with it's one hall and storage, bedrooms with balcony, etc.). Urban planning was done in simple way, using simple geometric forms and flat roofs, until 80s. Very rarely facades were colored; most of them consider the "beton-brut" appearance. Every apartment, except some at the ground floor, was planned with balcony or logia, with reach fenestration also. Apartments at the ground floor, built in 80 's, orientated at inner block-space, have their own garden.

According to actual technical regulations at the building period, the quality of insulation and infrastructure is various: from very poor at late 50 's to pretty well at late 80 's. The same standards were inherited from former SFRY as in Macedonia. First rules were adopted in 1967 (minimal technical requirement for apartment buildings' envelope regarding climatic zone) and 1970 (thermo insulation of buildings), but 1980 obligatory standard introduced, for the first time, the whole building thermo protection analysis. All subsequently adopted standards $(1987,1997,1998)$ improved 1980 regulations, but didn't consider the whole building energy consumption, energy rationalization possibilities or buildings environmental impact. New calculation methodology from 1998 also included specific rooms energy losses additionally to building losses calculation, but it remained in paper.

Fire safety is one of the key problems, specially in high residential buildings origin from this building period (1960-1990). Detailed regulations on fire protection, introduced in 1984, improved design solutions related to fire safety. Even then, prescriptive rules were simplified and often uniform solution was proposed resulting in the univocal rules, focused on the simplest solutions that were then extrapolated to larger models. Great part of the problem is lack of maintaining and updating fire protection measures in buildings [35], even it was obligatory action by low. The actual Fire safety low (2009) requires Fire protection building plan, which consist fire risk assessment and fire load calculation, so it would be of great impact on future buildings' renewal solutions.

The first seismic resistance building regulations were introduced in 1964 (former SFRY), after Skopje earthquake -1963, so it also can be said, as in case of Macedonia, that the residential multi-story buildings in Serbia, built according to those and subsequently adopted improvements $(1981,1982,1983,1988,1990)$, are in good condition and safe to relatively strong possible seismic activities.

Illegal building phenomena had skipped those city areas, only small adjustments were made by individual tenants (interventions at balcony or logia in order to expand the interior space by closing them). Local Agenda 21 (2001) proposes conceptual lines for improving sustainable city development, examining the possibilities of ecological building and reconstruction of built environment. Those principles are also incorporated in the last officially urban development plan, without realisation yet. 


\subsection{Large panel building block in Detelinara, Novi Sad}

The period of intensive applying of industrial construction technology in Novi Sad, as well as in Serbia, was the same period as in Bulgaria and Macedonia; 1960 - 1990. Both large panel and skeleton system prefabricated building construction method were applied. More than 67,000 residents of Novi Sad live in 23,600 flats built in industrial way. Average flat unit in Novi Sad is $57 \mathrm{~m}^{2}$ large, $20 \mathrm{~m}^{2}$ per resident. Large panel, high-industrialized system Montastan, was applied in short period (1980-89). Around 5,000 flats were built using this unique system, developed by domestic experts from Institute for industrial building - Faculty of Technical Science Novi Sad and "1. Maj" Backa Topola.

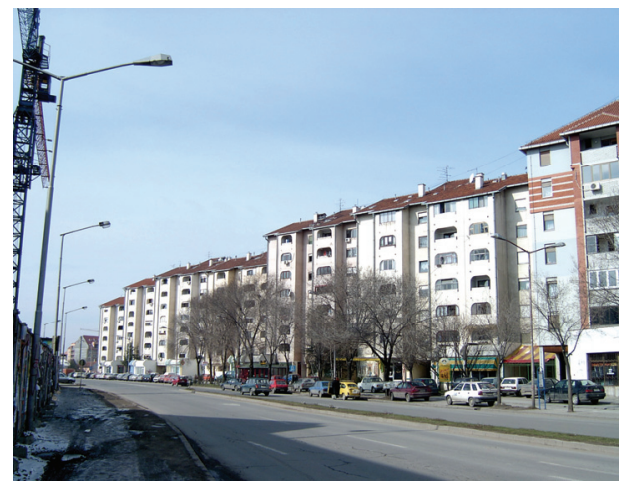

Fig. 12. Building block F4

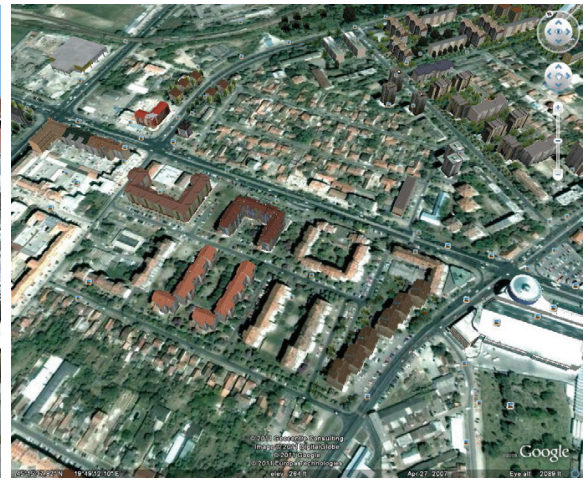

Fig. 13. Detelinara settlement

The system elements are prefabricated large panels (walls and floor slabs) made of fired clay blocks strengthened by RC, stairs, elevator shafts and sanitary cubicles. Crosswall bearing system was applied, with 3.6 or $4.2 \mathrm{~m}$ span and constructive height of $2.9 \mathrm{~m}$. Façade and apartment separating wall panels dimensions are $3.6(4.2) \times 2.9 \mathrm{~m}, 30 \mathrm{~cm}$ thick, and the thickness of load bearing internal wall panels is $22 \mathrm{~cm}$, same dimensions. All panels were finalized in factory with mortar layer and double glassed windows or door frames were built in. Partition walls in apartments were made as $7 \mathrm{~cm}$ thick brickwork. Floor slabs are grid RC structures with fired clay blocks infill, dimensions according to wall spans, $20 \mathrm{~cm}$ thickness. Sanitary cubicles were completely finished prefabricated box elements. Differently from all other industrial building systems applied in Novi Sad, Montastan is recognizable by double-pitched roofs (wooden construction covered with clay tile) and characteristically shaped loggias' openings.

Building block F 4 (Fig.12) in Detelinara (Fig.13) is east-west orientated, aligned to Braće Popovic street, built in 1987. Consists of five segments (6-7 floors), with 188 apartments in whole (studios, one or two bedrooms). The floor layout (Fig, 14) and flats are planed at satisfactory level (kitchen with separated storage and dining, connected to living room with balcony, two bedroom flats with separated extra toilet and quite nightpart of apartment with it's one hall and storage, bedrooms with balcony, etc.). Every apartment was planned with loggias and reach fenestration also. Street oriented ground floor part is commercial space, and the rest is technical rooms' space. Parking spaces are situated in internal block yard, along service streets. Green areas are well planed and maintained. Street façade is painted in white, but the yard façade is intensive coloured. 
Prefabricated facade panel, with characteristic loggia openings, is one of the most exploited shapes in industrialized building in Novi Sad (Fig. 15). Adding a few different details or intensive facade colouring, didn't prevent citizens to name those features ,portable TV buildings", so they became the symbols of monotony and the lack of urban identity. After all, illegal and unskilled interventions, made by residents, are the most often done on loggias: loggias are transformed to residential space - living room extension, separated bedroom, storage or extra kitchen. Besides sloppy impression and unfinished appearance, those interventions also contributed to façade deterioration process, due to bad insulation, ventilation and mould growth possibilities.

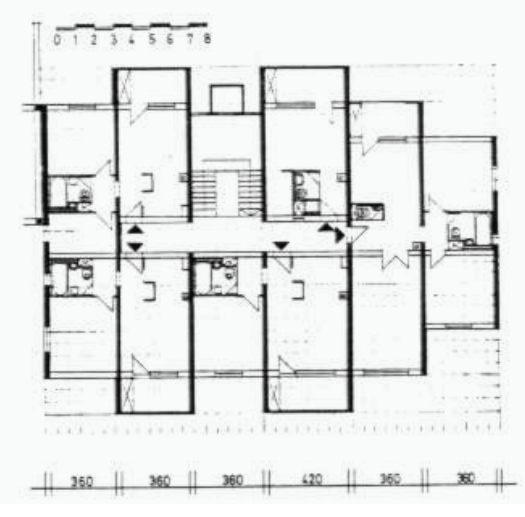

Fig. 14. Typical floor plan

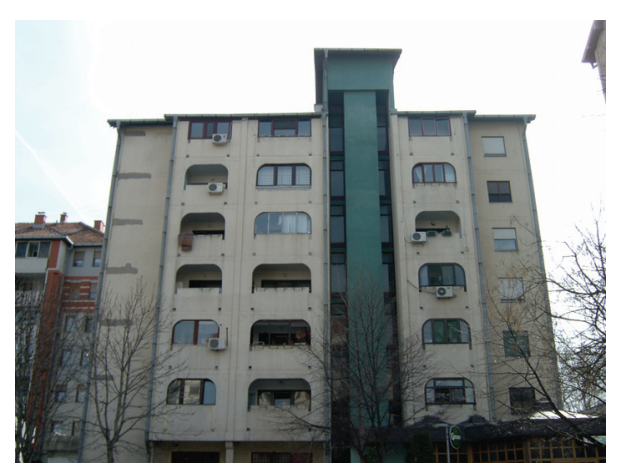

Fig. 15. Characteristic loggia openings

As any other large panel system, Montastan also has modest potential of flexibility, due to cross-wall bearing construction which doesn't allow any radical interventions. It is possible to make some rearrangements inside the modular span. Although innovated standards and technical rules regarding thermo insulation and fire safety were introduced in 80 s in Serbia, applied measures and solutions are insufficient according to contemporary demands. Seismic structural stability is still satisfactory in the most cases. The use of hazardous building materials isn't evidenced, except asbestos insulation in attics. Local Agenda 21 (2001) proposes conceptual lines for improving sustainable city development, examining the possibilities of ecological building and reconstruction of built environment. Those principles are also incorporated in the last officially urban development plan, but, so far, there were no funds to start any real action.

\section{COMPARATIVE ANALYSIS OF RESULTS AND CONCLUSIONS}

The industrial way of construction was applied at multifamily/multi-storey buildings, which were positioned on city edges, low density areas at that time, with poor infrastructure. The new-built housing blocks were unique and compact city areas in physical, technical and technological way, with characteristic appearance, shape, program, context and urban design, subordinated to residential function and city area disposition. City assembling and city shaping were impacted in characteristic way due to new building technology, and the look of the city and its' character has been changed permanently. 
Table 1. Morphological characteristics of analysed large panel building blocks

\begin{tabular}{|c|c|c|c|c|}
\hline \multirow[b]{2}{*}{$\begin{array}{l}\text { Large panel } \\
\text { building block }\end{array}$} & \multicolumn{4}{|c|}{ Morphological characteristics } \\
\hline & $\begin{array}{l}\text { Number of } \\
\text { stories }\end{array}$ & $\begin{array}{l}\text { Number of } \\
\text { apartments per } \\
\text { building }\end{array}$ & $\begin{array}{l}\text { Predominant } \\
\text { type of flat }\end{array}$ & $\begin{array}{l}\text { Average floor } \\
\text { space }\left(\mathrm{m}^{2}\right)\end{array}$ \\
\hline $\begin{array}{l}\text { Mladost 3, Sofia } \\
\text { Bulgaria }\end{array}$ & $\begin{array}{l}\mathrm{GF}+8 \\
\mathrm{GF}+10\end{array}$ & $21-27$ & $\begin{array}{l}\text { two bedroom } \\
\text { apartment }\end{array}$ & $75-80$ \\
\hline $\begin{array}{l}\text { Karpos, Skopje } \\
\text { Macedonia }\end{array}$ & $\mathrm{GF}+4$ & 16 & $\begin{array}{l}\text { one bedroom } \\
\text { apartment }\end{array}$ & 60 \\
\hline $\begin{array}{l}\text { Detelinara, Novi Sad } \\
\text { Serbia }\end{array}$ & $\begin{array}{l}\mathrm{GF}+6 \\
\mathrm{GF}+7\end{array}$ & $36-37$ & $\begin{array}{l}\text { one bedroom } \\
\text { apartment }\end{array}$ & 55 \\
\hline
\end{tabular}

Modest and simplified layout of buildings in analyzed case studies, with addition of more or less unskilled interventions and lack of proper maintains and chaotically built small shops in public space, contributes to generally pour appearance of urban blocks. Also, common problems are the lack of parking spaces and urban equipment, as well as absence of commercial or other social or public facilities in ground level of buildings. Internal block yards, foot-paths and entrances are usually neglected and bad lightened, which becomes also the safety problem.

Table 2. Building structure characteristics of analysed large panel building blocks

\begin{tabular}{|c|c|c|c|c|}
\hline \multirow{2}{*}{$\begin{array}{l}\text { Large } \\
\text { panel } \\
\text { building } \\
\text { block }\end{array}$} & \multicolumn{4}{|c|}{ Building structure characteristics } \\
\hline & Load bearing structure & Façade & Partition walls & Roof structure \\
\hline $\begin{array}{l}\text { Mladost } 3 \\
\text { Sofia } \\
\text { Bulgaria }\end{array}$ & $\begin{array}{l}\text { cross-wall system, } \\
3.6 \mathrm{~m} \text { span, } \\
\text { RC panels }(14 \mathrm{~cm}) \\
\text { RC slabs }(14 \mathrm{~cm})\end{array}$ & $\begin{array}{l}\text { Light concrete panels } \\
(20-26 \mathrm{~cm})\end{array}$ & RC panels $(6 \mathrm{~cm})$ & $\begin{array}{l}\text { flat, two RC panels } \\
(10 \mathrm{~cm}) \text { with } 1 \mathrm{~m} \text { gap } \\
\text { between }\end{array}$ \\
\hline $\begin{array}{l}\text { Karpos } \\
\text { Skopje } \\
\text { Macedonia }\end{array}$ & $\begin{array}{l}\text { cross-wall system, } \\
3.2 \mathrm{~m} \text { span, } \\
\text { RC panels }(12-14 \mathrm{~cm}) \\
\text { RC slabs }(10 \mathrm{~cm})\end{array}$ & $\begin{array}{l}\text { RC panel with } \\
\text { thermo insulation } \\
(\mathrm{RC} 14+\mathrm{TI} 6+\mathrm{RC} 5) \\
25 \mathrm{~cm}\end{array}$ & $\begin{array}{l}\text { RC panels } \\
(12-14 \mathrm{~cm})\end{array}$ & $\begin{array}{l}\text { low pitched roof } \\
\text { over RC slab and } \\
\text { insulation, bitumen } \\
\text { cover }\end{array}$ \\
\hline $\begin{array}{l}\text { Detelinara } \\
\text { Novi Sad } \\
\text { Serbia }\end{array}$ & $\begin{array}{l}\text { cross-wall system, } \\
3.6 \mathrm{~m} \text { span, } \\
\text { clay block }+\mathrm{RC} \text { panels } \\
(22 \mathrm{~cm}) \text { and slabs } \\
(20 \mathrm{~cm})\end{array}$ & $\begin{array}{l}\text { clay block +RC } \\
\text { panels }(30 \mathrm{~cm})\end{array}$ & $\begin{array}{l}\text { clay block }+\mathrm{RC} \\
\text { panels }(22 \mathrm{~cm}), \\
\text { brickwork }(7 \mathrm{~cm})\end{array}$ & $\begin{array}{l}\text { double-pitched roof, } \\
\text { wooden construction } \\
\text { covered with clay } \\
\text { tile }\end{array}$ \\
\hline
\end{tabular}

Large panel prefabricated residential buildings are still satisfactory regarding their morphological characteristics (Tab.1), with no more than 10 stories and average floor space of apartments. The bearing walls construction type (Tab. 2) is the main cause for non-flexible buildings' plans, although residents tried to achieve their needs for internal space redesigning on their own. All those interventions are to be reconsidered in eventually future renewal activities. Any future renovation activities should be based on structural evaluation (analysis of condition and performance) [36] as well as potential of multi- 
family housing life quality improvement and individualization [37] in order to achieve optimal service life and durability of buildings.

The seismic structural stability has to be reconsidered, although the buildings were built according to still actual standards. Past service period, pour maintaining and illegal building interventions could cause serious damages in case of future seismic activity. An absence of adequate fire protection measures is also common problem to be solved in order to achieve safety living environment. Fire risks should be assessed and decreased at acceptable level, for each building individually, according to contemporary fire safety engineering methods (Tab. 3).

Energy efficiency seams to be the common starting point of public interest and awareness, in all our three countries, that something has to be changed regarding our habits and mentality. Otherwise, it is going to cost us both financially and environmentally. Internal air quality should also be improved by applying proper hydro insulation, ventilation and replacement of asbestos and other hazardous building materials. The issue of accessibility was not an actual demand in the buildings' erection period, and it is still waiting for the right solution, in all three countries (Tab. 3).

Table 3. Reliability and sustainability of analysed large panel building blocks

\begin{tabular}{|c|c|c|c|c|c|}
\hline \multirow{2}{*}{$\begin{array}{l}\text { Large panel } \\
\text { building block }\end{array}$} & \multicolumn{2}{|c|}{ Reliability } & \multicolumn{3}{|c|}{ Sustainability } \\
\hline & $\begin{array}{l}\text { Seismic } \\
\text { resistance }\end{array}$ & Fire safety & $\begin{array}{l}\text { Energy } \\
\text { efficiency }\end{array}$ & IAQ & Accessibility \\
\hline $\begin{array}{l}\text { Mladost } 3 \\
\text { Sofia }\end{array}$ & Insufficient & Unsatisfactory & Insufficient & Insufficient & Unsatisfactory \\
\hline $\begin{array}{l}\text { Karpos } \\
\text { Skopje }\end{array}$ & Insufficient & Unsatisfactory & Insufficient & Insufficient & Unsatisfactory \\
\hline $\begin{array}{l}\text { Detelinara } \\
\text { Novi Sad }\end{array}$ & Satisfactory & Unsatisfactory & Insufficient & Satisfactory & Unsatisfactory \\
\hline
\end{tabular}

The huge number of flats, made in industrial way, needs a special care from government, politicians, architects and urban designers. Their usability depends on adequate structural safety and life safety performances. The energy performance and environment conscious solution is the major part of sustainability issues. Architectural, cultural and social questions have to be considered also, and final solutions have to be acceptable to residents and the community.

\section{REFERENCES}

1. The Sofia Declaration on the Future of the Large Prefabricated Housing Estates in Central and Eastern Europe http://www.eaue.de/Housing/sofiadek.htm (accessed July 2011)

2. Folić, R., Kurtović - Folić, N., "Pouzdanost i održavanje stambenih zgrada" Tehnika - Naše građevinarstvo 49 (1995) 9-10, str. NG1-NG11

3. Laban, M., »Kontrola kvaliteta prefabrikovanih betonskih fasadnih elemenata nakon višegodišnje eksploatacije «, Materijali i konstrukcije broj 1-2, 2006., str 3-19

4. Laban M., »Stanje hidroizolacije na višestambenim zgradama izgrađenim na industrijski način«, Zaštita materijala 2003, vol. 44 , br. 2-3, str. $75-80$

5. Laban, M. »Public wells in Novi Sad: Saving the water and city identity«, Scientific Symposium "Danube Basin and Sustainable Development", Novi Sad, 2005, CD ROM, p.12 
6. Laban, M. »Termoizolacione karakteristike fasadnog omotača u kontekstu energetskih performansi zgrade«, VIII međunarodni naučno-stručni skup YUCCOR 2006, Korozija i zaštita materijala u građevinarstvu, Tara, 2006

7. Milanko V., Laban M., Petrović - Gegić A., »Contribution to wastewater problem of inhabited places«, Scientific Symposium "Danube Basin and Sustainable Development", Novi Sad, 2005

8. Milanko V., Laban M., Karabasil, D., »Fire safety problems of residential towers«, 2nd international scientific conference FIRE ENGINEERING, Lučenec, Slovakia, 2006, Proceedings, pp. 255.-261

9. Pešević B., Naumov M., Davidović Z., Laban M., »Illegal Building Phenomena and Sustainable Urban Development«, The VIIIth International Symposium "Young people and multidisciplinary research", Temišvar, Romania, 2006

10. Hadjimichael, G., Introduction, COST C16 Improving the Quality of Existing Urban Building Envelopes - Needs. E. Melgaard, G.Hadjimichael, M. Almeida, L.G.W. Verhoef (eds.) IOS Press, 2007, pg 1-4.

11. fib TG 5.1. "Monitoring and safety evaluation of existing concrete structures", International Federation for Structural Concrete, Lausanne, Switzerland, 2003

12. McMullan, R., "Environmental Science in Building", Palgrave MacMullan, New York, USA, 2002

13. fib TG 3.6 "Environmental design of concrete structures -general principles", International Federation for Structural Concrete, Lausanne, Switzerland, 2008

14. Curwell, S. et.al. "Hazardous Building Materials", Spoon Press, New York, USA. 2008

15. Godish, T., "Sick Buildings: definition, diagnosis and mitigation", Lewis Publ. Boca Raton, USA, 1995

16. OPET BUILDING, Inovative concepts and technologgies for residential building refurbishment, Country Report, Sofia Energy Centre, National Report: The residential building sector in Bulgaria, http://www.sec.bg/userfiles/file/Opet\%20Building/country_reportBG.pdf (acssesed july, 2011)

17. Report for European Housing Ministers' Conference, Prague, Czech Republic, 14 - 15 March 2005, Sustainable Refurbishment of High-Rise Residential Buildings and Restructuring of Surrounding Areas http://www.iut.nu/EU/HousingMinistersMeetings/2005/Conference_BackGr_Doc.pdf (acssesed july, 2011)

18. Savov, R., Beloeva, V., Refurbishment of Social Buildings in Bulgaria - Specific problems and Solutions, The CRES conference proceedings "Retrofitting of Social Housing-Financing and Policy Options", 7-8 November 2006, Thessaloniki, Greece, http://www.cres.gr/conference/proceedings.htm (acssesed july, 2011)

19. RESHAPE: Retrofitting Social Housing and Active Preparation for EPBD (2006-2008), http://www.reshape-social-housing.eu/ (acssesed july, 2011)

20. SHARE: Social Housing Action to Reduse Energy Consumption (2006-2008), http://www.socialhousingaction.com/social\%20housing\%20in\%20Bulgaria.htm (acssesed july, 2011)

21. ROSH: Development and marketing of integrated concepts for energy efficient and sustainable retrofitting of social housing (2006-2008), http://www.rosh-project.eu/ (acssesed july, 2011)

22. EI-Education: Energy Intelligent Education for Retrofitting of Social Houses (2006-2007), http://eieducation.aarch.dk/ (acssesed july, 2011)

23. ISEES: Improving the Social Dialogue for Energy Efficiant Social Housing (2006-2007) http://ec.europa.eu/energy/intelligent/projects/doc/slides/isees.ppt\#1 (acssesed july, 2011)

24. INOFIN: Innovative Financing of Social Housing Refurbishment in Enlarged Europe, 2006-2007, http://www.join-inofin.eu/ (acssesed july, 2011)

25. National Program for Renovation of Multifamily buildings in Republic of Bulgaria, http://www.obnovendom.com

26. EA.UE: European Academy of the Urban Environment, Large prefabricated housing estates in Central and Eastern Europe, City of Sofia, http://www.eaue.de/Housing/houssofi.htm (accessed in July, 2011)

27. ESRU: Predictive Modelling of a Building in Sofia, Bulgaria, 2008, http://www.strath.ac.uk/media/departments/mechanicalengineering/esru/modellingapproach/othercasestudies/Predictive_Modelling_of_a_Building_in_Sofia,_Bulgaria.pdf (accessed in June 2011)

28. Проект "Демонстрационно обновяване на многофамилни жилищни сгради" National Program for Renovation of Multifamily buildings in Republic of Bulgaria, The Demonstration Project for the Renovation of Multifamily Buildings, http://www.obnovendom.com/?p=775 (acssesed july, 2011)

29. Stojkov, T. State of the Art: F.Y.R. of Macedonia, Improving the Quality of Existing Urban Building Envelopes - State of the Art. M.T. Andeweg, et al. (eds.) IOS Press, 2007, pg 195-209

30. Stojkov, T., Review of some practical solutions in improving the quality of multi-story family houses built in 1950s and 60s in Macedonia, COST Action C-16, Meeting in Skopje, July, 2003

31. Stojkov, T., General Overview of the Problems, Needs and Solutions in the Macedonian Urban Building Envelopes, COST C16 Improving the Quality of Existing Urban Building Envelopes - Needs. E. Melgaard, et al. (eds.) IOS Press, 2007,pg 81-88 
32. Gramatikov, K., Bozinovski, Z., Enlargement of Balconies of Existing Residential Building "Karpos" in Skopje, Improving the Quality of Existing Urban Building Envelopes - Structures, R. di Giulio, Z. Bozinovski, L.G.W. Verhoef (eds.), IOS Press, 2007, pg 91-97

33. Trpevski, S., Technical Improvement of Housing Envelopes in the F.Y.R. of Macedonia, COST C16 Improving the Quality of Existing Urban Building Envelopes - Facades and Roofs. L. Bragança, C. Wetzel, V. Buhagiar, L.G.Werhoef (eds.) IOS Press, 2007, pp 83-94

34. Laban, M., Industrijska izgradnja visestambenih zgrada u Novom Sadu, magistarski rad, Univerzitet u Novom Sadu, Fakultet tehničkih nauka, Novi Sad, 2005., str. 246

35. Laban M., Milanko V., »Fire safety assessment in urban environment« International Scientific Publications: Ecology \& Safety, 2008 Vol 2, pp121-133

36. Folic, R. Durability Design of Concrete Structures - Part 1: Analysis fundamentals, FACTA UNIVERSITATIS Series: Architecture and Civil Engineering Vol. 7, No 1, 2009, pp. 1 - 18

37. Stoiljkovic, B., Jovanovic, G., Potential and Importance of Multi-Family Housing Individualization, FACTA UNIVERSITATIS Series: Architecture and Civil Engineering Vol. 8, No 4, 2010, pp. 361 - 374

\section{ANALIZA POUZDANOSTI I ODRŽIVOSTI KRUPNO PANELNIH STAMBENIH BLOKOVA U SOFIJI, SKOPLJU I NOVOM SADU}

\section{Radomir Folić, Mirjana Laban, Verica Milanko}

Krupnopanelne prefabrikovane stambene zgrade su građene u drugoj polovini XX veka u skoro svim gradovima Evrope. U ovom radu, u kontekstu tri studije slučaja urbanih blokova u Bugarskoj (Mladost - Sofija), Makedoniji (Karpoš III - Skoplje) i Srbiji (Detelinara - Novi Sad), sprovedena je komparativna analiza i evaluacija tehničkih i konstruktivnih karakteristika prema kriterijumima pouzdanosti (seizmička otpornost i požarna bezbednost) i održivosti (energetska efikasnost, kvalitet unutrašnjeg vazduha, pristupačnost). Dat je i sažet prikaz iskustava iz dosadašnjih projekata obnove pojedinih objekata. Iskustva i rezultati komparativne analize mogu doprineti formulisanju šire primenljivih rešenja i razvoju savremenih/novih strategija obnove gradova.

Key words: krupno panelne stambene zgrade, komparativna analiza, pouzdanost, održivost, obnova. 